\title{
Can the Housing Policies Sustain House Prices in Malaysia?*
}

\author{
Geok Peng Yeap ${ }^{a}$ \\ Hooi Hooi Lean ${ }^{b}$ \\ Universiti Sains Malaysia
}

\begin{abstract}
In addition to economic factors, this paper examines the impact of housing policies in sustaining house prices in Malaysia at both aggregate and disaggregate levels. By using autoregressive distributed lag (ARDL) framework, we develop a model of house price determination with a focus on two major housing policies - mortgage interest tax relief (MITR) and Developer Interest Bearing Scheme (DIBS). Although aggregate house prices do not react to any economic variable in the long run, it responds positively to interest rate and DIBS in the short run. At the disaggregate level, population and housing stock influence house prices in the long run. Nonetheless, MITR and DIBS have a statistically significant positive impact on the price of highrise houses. We conclude that while demand and supply variables are important determinants of house prices in the long run, house price changes are affected by housing policies in the short run. For policy recommendation, we suggest to strictly prohibit DIBS to ensure a stable growth in the housing market. Besides that, MITR should be implemented to ensure housing affordability and to stimulate the housing market during recession.
\end{abstract}

Keywords: Developer interest bearing scheme, house prices, housing policies, Malaysia, mortgage interest tax relief

JEL classification: R21, R30, R38

\section{Introduction}

The housing market in Malaysia is highly regulated and monitored by the government because it is an important sector that supports the sustainable growth of the economy. Like many other countries in the world, Malaysia has experienced a rapid house price appreciation in the past few years, especially in more developed areas like Kuala Lumpur, Johor and Penang. House prices have increased and exceeded the growth rate of consumer prices as well as the growth rate of income. From 2010 to 2015, Malaysia's aggregate house prices (measured by Malaysian House Price Index) increased by 61.1 percent and 70-72 percent in Kuala Lumpur, Johor and Penang ${ }^{1}$ while consumer price index (CPI) and income grew by only 12.8 percent $^{2}$ and 29.5 percent ${ }^{3}$ respectively during

* We gratefully acknowledge Research University Grant Scheme 1001/PSOSIAL/816302 supported by Universiti Sains Malaysia.

a Economics Program, School of Social Sciences, Universiti Sains Malaysia, 11800 USM, Penang, Malaysia. Email:gpyeap@gmail.com

b Economics Program, School of Social Sciences, Universiti Sains Malaysia, 11800 USM, Penang, Malaysia. Email: hooilean@usm.my (Corresponding author)

1 Calculated as the percentage change in house price index for the respective states between 2010 and 2015.

2 Calculated as the percentage change in consumer price index between 2010 and 2015.

3 Calculated as the percentage change in gross domestic product at constant prices between 2010 and 2015. 
the same period. Looking at the housing sub-markets for different types of houses detached, semi-detached, terraced and high-rise - prices increased by 59.9 percent, 54.7 percent, 59.2 percent and 78.9 percent respectively between 2010 and 2015 .

Due to the escalating house prices in the country and the concern over housing affordability, the government introduced some policy measures in the housing market. In this study, we mainly focus on two housing policies - mortgage interest tax relief (MITR) and Developer Interest Bearing Scheme (DIBS). MITR is a government stimulus program implemented during the global financial crisis (GFC) which aimed to increase homeownership in the country by easing the burden of people in purchasing houses. Under this policy, house buyers who signed the Sale and Purchase Agreement (S\&P) from 10 March 2009 to 31 December 2010 were given tax relief on interest paid on housing loans up to RM10,000 per year for three consecutive years. For a property with joint purchasers, all purchasers were entitled to tax relief on the interest incurred by the housing loan proportionately to the interest they had paid. However, property developers claimed that this policy could not stimulate the property sector because it does not directly subsidise potential homebuyers by putting money into their hands (Fong, 2009). Additionally, the effectiveness of this policy is ambiguous because the execution period was relatively short.

DIBS is an initiative introduced by property developers in 2009 as a marketing tool to promote property in the primary market. Under the DIBS, property developers will bear the interest payment of home loans during the construction period. It provides a low entry cost for homebuyers because they have no obligation to serve their loan payments during the construction period. Some developers even promoted DIBS as a built-to-sell system to attract homebuyers. As such, purchasing a house with DIBS feature is perceived as excellent investment opportunities which encouraged more speculative activities in the housing market. In fact, property developers who adopt DIBS tend to incorporate interest payment into house prices and cause higher house prices in the country. According to Bank Negara Malaysia (BNM), DIBS contributed to the surge in house prices by about 30 percent (BNM, 2013). DIBS encourages more credit in the residential sector and consequently contributes to the risks of rising household debt, which will lead to unsustainable growth in the long run. Hence, to ensure stable and sustainable growth of the housing and financial markets, DIBS was prohibited starting from January 2014. However, recently, due to slowing down of the housing market, some private developers have urged the government to allow DIBS for first-time homebuyers.

Therefore, the purpose of this study is to find out whether government housing policies had a significant influence on house prices in Malaysia over the period 2002 to 2015. In particular, this paper poses two main questions: (1) Was MITR able to significantly sustain house prices in Malaysia? (2) Did DIBS significantly cause the increase of house prices in Malaysia? We contribute to the literature on the housing market in Malaysia by developing a model for house price determination that emphasises on two major housing policies: MITR and DIBS. While Malaysia's government has implemented a series of housing policies intended towards maintaining the stability of the housing market and to work towards solving the issue of housing unaffordability especially among the lower and middle income classes of society, none of the empirical studies in Malaysia so far examines the impact of these policies. 
The current scenario of continuously escalating house prices casts doubt on the effectiveness of the said government policies and interventions in the housing market. These policies and interventions could result in structural changes in the housing market. Based on the results from the autoregressive distributed lag (ARDL) framework, this paper seeks to assess the impact of the above mentioned policies in both the long run and short run. It is the first attempt to quantify the impact of these housing policies and whether they affect house prices and hence allow for the evaluation of their effectiveness in the housing market. This paper adds to the literature by examining the disaggregate house prices. All previous studies that attempted to examine the impact of government policies only focus on aggregate house prices at the national level (see e.g. Barrell, Kirby, \& Riley, 2004; Lum, 2002; Phang \& Wong, 1997; Tu, 2003). This is the first study to analyse the effect of government housing policies on house prices in Malaysia focusing on both the aggregate and disaggregate levels.

This paper is organised as follows. Section 2 provides a review of literatures regarding government housing policies. Section 3 presents the data and empirical model used in this study. In Section 4, we discuss the results of the analysed data, while Section 5 provides the conclusion of this paper.

\section{Literature Review}

With reference to previous literature on housing, various studies professed economic fundamentals to have good explanatory power in house prices (Abelson, Joyeux, Milunovich, \& Chung, 2005; Glindro, Subhanij, Szeto, \& Zhu, 2011; Himmelberg, Mayer, \& Sinai, 2005; Li \& Chand, 2015; Munro \& Tu, 1996; Otto, 2007; Stevenson, 2008). On the demand-side, the professed explanatory factors are income, mortgage interest rate and demographic factors such as population. Income remains one of the most important factors in the short run as well as in the long run as professed in almost all the studies. On the supply-side, determinants of house prices include housing stock, construction cost and land prices (Kenny, 1999; 2003; McCarthy \& Peach, 2004; Steiner, 2010; Zhou, 2010). The dynamics of house prices are also considered in terms of market disequilibrium, where the interaction of demand and supply is addressed to predict housing price trends (Riddel, 2004; Stevenson \& Young, 2014; Wigren \& Wilhelmsson, 2007).

Some studies turned to examining the influence of changes in government policies on the price of houses. According to Rosen (1985), government interventions in the housing market could take several forms. These include housing codes, which set the quality standards that must be met by the property developers; licensure of real estate brokers; land use regulation; laws which prohibit discrimination in selling of houses; regulations on mortgage lending and interest rate; real estate taxation and interventions in the credit market.

\subsection{Studies on Mortgage Interest Tax Relief}

Among the housing policies, mortgage interest tax relief is one of the popular policies discussed in academic research. This tax system is regarded as housing subsidies where interest payments on housing loans are deductible from taxable income. It lowers the 
cost of consumption on housing services and creates an incentive to homeownership (Glaeser \& Shapiro, 2003; Heylen, 2013). Hence, an increase in homeownership rate is believed to result in higher house prices.

There are arguments on the pros and cons of mortgage interest deduction. The supporters of this policy believe that the increase in homeownership helps to increase home maintenance and gardening, which in turn improves the quality of neighbourhoods. This seems to generate positive externalities from homeownership (Glaeser \& Shapiro, 2003). On the other hand, critiques of mortgage interest tax relief stress that the policy reduces the income tax revenue collected by government, and it benefits the wealthiest homeowners (Glaeser \& Shapiro, 2003; Jappelli \& Pistaferri, 2007). Noticeably, this policy provides subsidies to those who have mortgage loans only, and consequently there is misallocation of housing wealth towards the higher income group. Glaeser and Shapiro (2003) argued that mortgage interest deduction is a poor instrument for homeownership because it favours the rich by subsidising those who are always the homeowners. They found an insignificant impact of mortgage interest deduction on homeownership rate. Hanson (2012) also found no relationship between mortgage interest deduction and homeownership; but mortgage interest deduction could explain the increased number of home purchased. However, Rosen (1985) showed that mortgage interest payment deduction is an important determinant of homeownership among the middle class Americans. However, these papers succeeded in explaining the impact of MITR on homeownership but failed to examine the direct impact of MITR on house prices.

In fact, mortgage interest tax relief has been implemented in many European countries but it has been gradually abolished, due to the regressive effects it has demonstrated (Matsaganis \& Flevotomou, 2007). In the UK, Barrell et al. (2004) used a dummy variable with a value of one to capture the abolition of mortgage interest tax relief. They believed that mortgage interest tax relief drives up house prices because young house buyers actively purchased these houses before the abolition. But, the study has not found any significant effect of mortgage interest tax relief on house prices. The evaluation provided by Gibb and Whitehead (2007) explained that the policy has no impact on house prices, but the removal of mortgage tax relief is effective because it results to a reduction in public expenditure without having a negative effect on the housing market.

\subsection{Other Types of Government Policies in the Housing Market}

Beside the government tax policies that tackle the demand for housing, some other studies focused on land use policies that tackled the supply of housing. The argument is that low level of land sales owned by the government is associated with higher house prices. For instance, Lum (2002) examined the impact of land release policy implemented by the Singapore government during the 1990s. Under this policy, the government released state-owned land for private residential development. The author found that government land sales policy is an effective tool to reduce private residential housing prices. In addition, both Lum (2002) and Phang and Wong (1997) believed that government policies such as public housing policies, the supply of state land for private 
housing developments and the rules governing the use of Central Provident Fund savings, could impact private housing prices in Singapore. Both studies applied dummy variables to estimate the effects of the mentioned government policies on house prices and they concluded that housing related government policies play an important role in explaining short-run house price changes.

Furthermore, Tu (2003) studied nine housing policies implemented by the Singapore government from 1990 to 1999 . These housing policies are with regard to public resale housing policies and anti-speculation measures targeted at curbing the overheated property market in Singapore in the 1990s. Many house buyers in Singapore made use of the subsidised public housing as a medium to own a property in the private housing market by re-selling the public housing after a minimum occupancy period. This could have led to indirect transfer of public housing subsidies to finance private housing and create unequal distribution of public resources. Hence, it is claimed that public resale housing policies affect the private housing price volatilities. By using dummy variables to represent housing policies, the author found that liberalisation of finance terms significantly impact public house prices, while anti-speculation measures significantly impact private house prices. The studies mentioned in this section examined the impact of other types of government policies on the housing market, particularly in Singapore. To the best of our knowledge, none of the studies investigated the impact of DIBS on house prices.

\subsection{Related Studies in Malaysia}

In Malaysia, Lean and Smyth (2014) and Ibrahim and Law (2014) are two notable studies in this field. Generally, these studies demonstrated that house prices are cointegrated with fundamental variables such as stock price, real output, interest rate and bank credits. Other similar studies in Malaysia include Hui (2013) and Tang and Tan (2015). However, we notice that these papers are based on house prices and economic fundamentals. None of these studies examine the impact of housing policies on house prices, in particular, the potential impacts of MITR and DIBS have been largely ignored. Supposedly, house prices in Malaysia are affected by the determinants of both demand and supply as well as by government policies. As such, we make the first attempt to study the important role of housing policies in explaining the fluctuations of house prices in Malaysia.

\section{Research Method}

\subsection{Data}

The sample period is from $2002 \mathrm{Q} 3$ to $2015 \mathrm{Q} 4$ based on data availability. The Malaysian House Price Index published by the National Property Information Centre (NAPIC) is used to represent house prices. In the analysis, we consider house price indexes at both aggregate and disaggregate levels. Disaggregate house price indexes include four housing sub-markets which are: detached house price index (HPD), semi-detached house price index (HPS), terraced house price index (HPT) and high-rise house price index $(\mathrm{HPH})$. 
The independent variables used in this study include income levels, interest rates, housing stocks and population sizes. Income is found to be the single most important factor that determines house prices. Numerous studies in the housing market have used real gross domestic product (GDP) to measure income (e.g. Malpezzi \& Maclennan, 2001; Ibrahim and Law, 2014). Interest rate is used as a proxy for the user cost of holding housing assets. In this study, we use the Base Lending Rate (BLR) as a measure of interest rate. Prior to 2 January 2015, BLR was the main reference rate for housing loans. BLR has been used in previous studies such as Lean and Smyth (2014) and Yeap and Lean (2017). Besides that, housing stock is included in the house price equation to capture the feedback effect of housing supply to house prices (Meen, 2002). In this study, existing stocks of housing is used to measure housing stock. Lastly, we include population size to represent the demographic factor. The demographic factor is an important determinant of housing demand and therefore affects house prices (Poterba, 1991). The data used for GDP, BLR and population are obtained from the BNM Monthly Statistical Bulletin whereas existing stocks of housing are collected from NAPIC.

Two dummy variables are used to capture the impact of change in government policies on the housing market. The first dummy $\left(D_{\text {MITR }}\right)$ represents the period of MITR implementation. $D_{\text {MITR }}$ takes value 1 from 2009 Q2 to $2010 Q 4$ and 0 otherwise. The second dummy variable $\left(D_{\text {DIBS }}\right.$ ) represents DIBS which takes value 1 from 2009 Q 2 to $2013 \mathrm{Q} 4$ and 0 otherwise.

\subsection{Empirical Model}

Economic theories suggest that the long-run equilibrium house price can be determined through the interaction between demand and supply of housing. The demand for housing services is determined by house prices and a set of demand shifting variables such as income, user cost of housing services and demographic factors like population. On the other hand, the supply of housing is determined by new construction and the level of existing housing stock in the previous period net of depreciation. Hence, house price is a function of existing housing stocks and demand shifting variables.

The inverted demand equation is commonly used in many empirical studies in examining house prices (e.g. Abelson et al., 2005; Anundsen, 2015). However, besides economic variables, change in government policies is believed to influence house prices. As claimed by Buckley and Ermisch (1982), government policy influences the functioning of the housing market and it should be understood through various factors that affect house prices. Similarly, Poon and Garratt (2012) argued that policies, procedures and incentives related to housing supply contribute to highly-priced inelastic housing supply which drives up house prices and reduces affordability. Poterba (1992) also argued that government tax policies reduce incentives for housing investment and contribute to the decline in new housing and thus, lead to higher rents. As such, government interventions or policy changes are an important source of structural change in the housing market that should not be left out.

We specify the long-run house price equation in ARDL framework (Pesaran, Shin, \& Smith, 2001) as follows: 


$$
\begin{aligned}
\ln H P_{t}= & \gamma_{0}+\sum_{i=1}^{m 1} \gamma_{1 i} \ln H P_{t-i}+\sum_{i=0}^{m 2} \gamma_{2 i} \ln G D P_{t-i}+\sum_{i=0}^{m 3} \gamma_{3 i} B L R_{t-i}+\sum_{i=0}^{m 4} \gamma_{4 i} \ln P O P_{t-i} \\
& +\sum_{i=0}^{m 5} \gamma_{5 i} \ln E S_{t-i}+\gamma_{6} D_{\text {MITR }}+\gamma_{7} D_{\text {DIBS }}+\mu_{t}
\end{aligned}
$$

where HP, GDP and BLR represent house price, income and interest rate respectively. POP and ES represent population and existing housing stock respectively. $D_{\text {MITR }}$ is the dummy variable that represents mortgage interest tax relief whereas $D_{\text {DIBS }}$ is the dummy variable that represents developer interest bearing scheme. The optimum lags $\left(m_{1}, m_{2}\right.$, $m_{3}, m_{4}$ and $m_{5}$ ) will be selected based on Schwarz Information Criteria (SIC). With the quarterly data used in this study, we set the maximum lag as four.

The restricted error-correction model (ECM) of Equation (1) is specified as follows:

$$
\begin{aligned}
\Delta \ln H P_{t}= & \tau_{0}+\tau_{1} E C T_{t-1}+\sum_{i=1}^{m 1-1} \lambda_{1 i} \Delta \ln H P_{t-i}+\sum_{i=0}^{m 2-1} \lambda_{2 i} \Delta \ln G D P_{t-i}+\sum_{i=0}^{m 3-1} \lambda_{3 i} \Delta B L R_{t-i} \\
& +\sum_{i=0}^{m 4-1} \lambda_{4 i} \Delta \ln P O P_{t-i}+\sum_{i=0}^{m 5-1} \lambda_{5 i} \Delta \ln E S_{t-i}+\lambda_{6} D_{\text {MITR }}+\lambda_{7} D_{D I B S}+\varepsilon_{t}
\end{aligned}
$$

where $E C T_{t}=\ln H P_{t}-a-b_{1} \operatorname{lnGDP}_{t}-b_{2} B L R_{t}-b_{3} \ln P O P_{t}-b_{4} \operatorname{lnES} S_{t}-b_{5} D_{M I T R, t}-b_{6} D_{D I B S, t}$. The coefficient of the error correction term $\left(\tau_{1}\right)$ denotes the speed of adjustment of house prices to the long-run equilibrium. First, we perform bounds test to examine the null hypothesis that there is no cointegration among the variables by checking the F-statistics with the critical values provided by Narayan (2005). We then estimate the long-run coefficients of the explanatory variables from equation (2) which are given as $b_{i}$, while the short-run coefficients of the explanatory variables are given as $\Sigma \lambda_{k i}$ respectively.

\section{Results and Analysis}

House price changes vary significantly across dwelling types. Figure 1 presents the annual change in house prices between 2002Q3 and 2015Q4. Generally, annual changes in house prices have deviated upward since 2009. This trend coincides with Malaysia's second stimulus package in March 2009. The MITR was one of the fiscal measures announced under this package. At the same time, DIBS was first introduced in early 2009 as well. These policy interventions had resulted in a structural change in house prices. As can be seen from the diagrams, the average annual increase in aggregate and disaggregate house prices between 2011 and 2015 is significantly higher than the period between 2002 and 2009. Price of non-landed houses (HPH) recorded the highest average annual increase compared to landed houses (HPD, HPS and HPT).

To examine the stationarity of all variables, augmented Dickey-Fuller (ADF) and Phillips-Perron (PP) unit root tests are employed. Besides that, we also complement the analysis with Zivot and Andrew (ZA) unit root test, to endogenously detect the possible existence of structural break. We use ZA test which allows for a break in both intercept and trend to perform the analysis. The overall results of unit root tests are reported in 

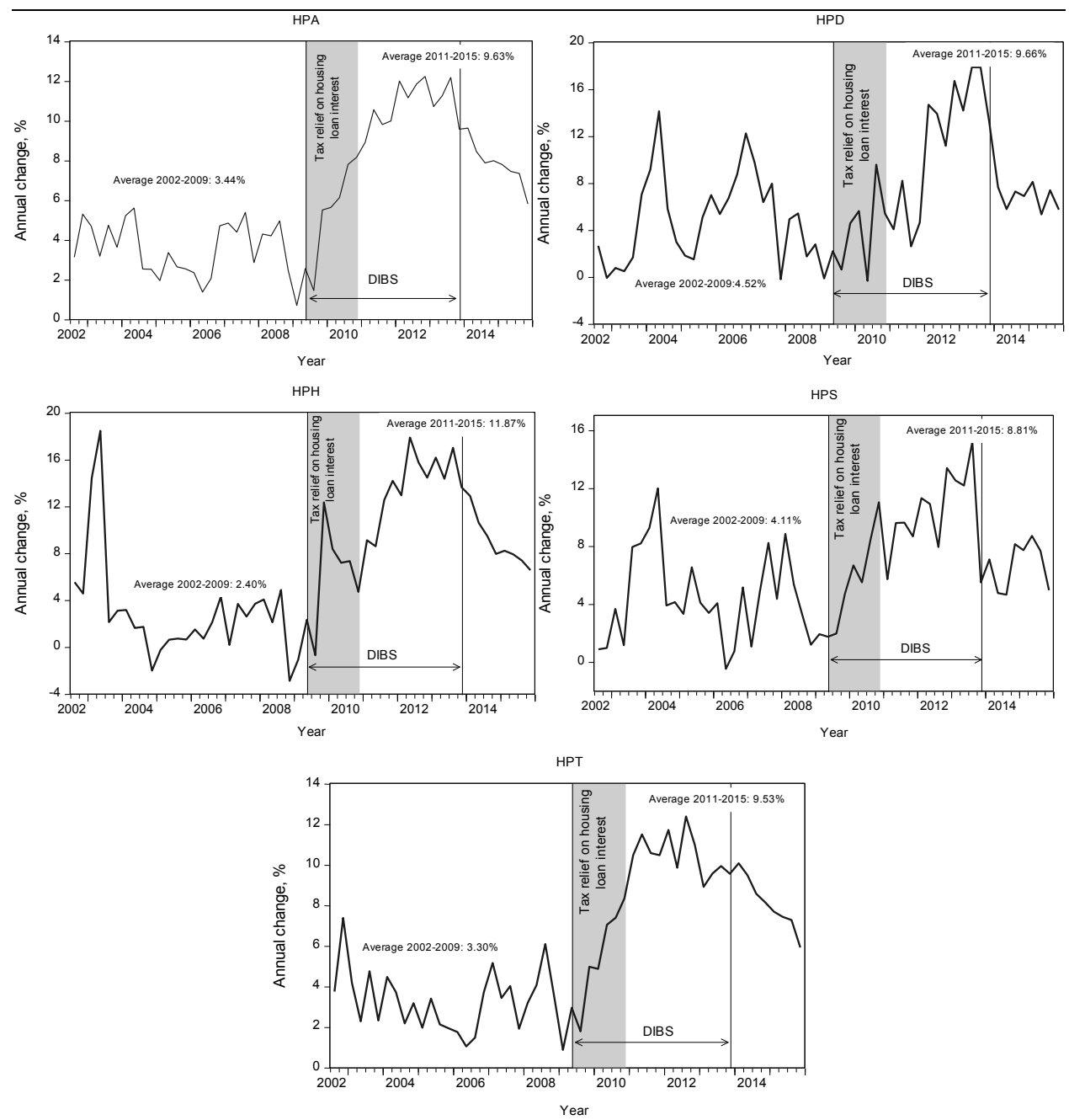

Figure 1. Annual changes in house prices

Table 1. The results of ADF and PP unit root tests show that all variables are stationary in their first differences except for existing stock of aggregate houses (ESA), existing stock of detached houses (ESD), existing stock of high-rise houses (ESH), existing stock of semi-detached houses (ESS) and existing stock of terraced houses (EST) which are stationary in their level. The structural break point for all house price indices detected by ZA unit root test falls on 2008Q4. This points towards a structural break around the GFC where the Malaysian economy started to be affected in the fourth quarter of 2008 as reported in BNM (2009). The results of the unit root tests confirm that none of the variables are integrated in order two, I(2) and the ARDL bounds test can be used to test for cointegration of the variables. 
Table 1. Unit root tests

\begin{tabular}{|c|c|c|c|c|c|c|c|}
\hline & $\begin{array}{r}\text { Z } \\
\text { (Intercept }\end{array}$ & A & $\begin{array}{r}\mathrm{A} \\
\text { (Intercept }\end{array}$ & $\begin{array}{l}\text { DF } \\
\text { and trend) }\end{array}$ & (Intercept & and trend) & \\
\hline & Level & Break point & Level & First diff & Level & First diff & \\
\hline HPA & $-4.9589 * * *$ & $2008 Q 4$ & -0.8144 & $-7.4153 * * *$ & -0.8277 & $-7.4339 * * *$ & $\mathrm{I}(1)$ \\
\hline HPD & $-4.1552 * * *$ & $2008 Q 4$ & -1.8961 & $-8.7943 * * *$ & -1.7591 & $-8.9325 * * *$ & $I(1)$ \\
\hline $\mathrm{HPH}$ & $-4.6041^{* * *}$ & $2008 Q 4$ & -0.8631 & $-9.6502 * * *$ & -0.8638 & $-9.3967 * * *$ & $I(1)$ \\
\hline HPS & $-3.7428 * *$ & $2008 Q 4$ & -0.9163 & $-11.373^{* * *}$ & -1.3364 & $-11.272^{* * *}$ & I(1) \\
\hline HPT & $-4.8703 * * *$ & $2008 Q 4$ & -0.8112 & $-8.4192 * * *$ & -0.7319 & $-8.4188 * * *$ & $\mathrm{I}(1)$ \\
\hline GDP & $-6.8375^{* * *}$ & $2008 Q 4$ & -3.3554 & $-3.5542 * * *$ & -2.2251 & $-8.9292 * * *$ & $\mid(1)$ \\
\hline BLR & $-5.2945^{* * *}$ & $2008 Q 4$ & -2.7246 & $-5.1834 * * *$ & -2.3974 & $-5.1873 * * *$ & I(1) \\
\hline POP & $-2.6674^{* *}$ & $2013 Q 1$ & -0.6003 & $-4.3639 * * *$ & 0.3982 & $-4.3639 * * *$ & $\mathrm{I}(1)$ \\
\hline ESA & $-5.4178 * *$ & 2007Q2 & $-3.5036^{* *}$ & $-7.5741^{* * *}$ & $-11.108 * * *$ & $-7.5682 * * *$ & $I(0)$ \\
\hline ESD & $-4.5461 * * *$ & 2012Q1 & $-4.0256 * *$ & $-8.1166 * *$ & $-4.0568 * * *$ & $-8.1587 * * *$ & $I(0)$ \\
\hline ESH & $-4.6902 * * *$ & $2007 Q 2$ & $-4.0667^{* *}$ & $-6.6542 * * *$ & $-4.6525 * * *$ & $-6.6513 * * *$ & $\mathrm{I}(0)$ \\
\hline ESS & $-8.3121^{* * *}$ & $2007 Q 4$ & $-7.3995 * * *$ & $-8.4398 * * *$ & $-7.4023 * * *$ & $-53.382^{* * *}$ & $I(0)$ \\
\hline EST & $-6.2703 * * *$ & 2006Q4 & -1.8700 & -1.3563 & $-3.9242 * *$ & $-7.5228 * *$ & $I(0)$ \\
\hline
\end{tabular}

Note: $* * *(* *)$ denote significance at $1 \%(5 \%)$ respectively. HPA: aggregate houses price; HPD: detached houses price; HPH: high-rise houses price; HPS: semi-detached houses price; HPT: terraced houses price; GDP: real gross domestic product; BLR: base lending rate; ESA: existing stock of aggregate houses; ESD: existing stock of detached houses; ESH: existing stock of high-rise houses; ESS: existing stock of semi-detached houses; EST: existing stock of terraced houses.

Table 2 presents the ARDL estimation results of Equation (2). The bounds test results indicate the existence of cointegration between house prices and real GDP, BLR, population and housing stock for aggregate house price and all types of houses except for HPD. The existence of cointegration suggests that house prices and the fundamental variables tend to move together in the long run.

In the long run, we find that population is the major driver of house prices. Increase in population would significantly increase the prices of high-rise, terraced and detached houses as a result of increasing demand for housing. Besides that, existing housing stock is found to negatively influence HPH and HPT. The inclusion of housing stock allows us to examine the impact of housing supply to prices. The findings show that an increase in total supply of residential units will result in a fall in house prices. Although real GDP and BLR have not statistically influenced house prices significantly, it is surprising that real GDP has a significant negative effect on HPT. This finding reveals that prices of terraced houses have continued to rise despite the slowdown of the economy during the 2008 GFC.

Turning to the short-run analysis, the coefficient of lagged error-correction term $\left(E C T_{t-1}\right)$ is negative and significant for all cases. This again supports the existence of long-run relationship between house prices and all explanatory variables. The speed 
Table 2. ARDL results

\begin{tabular}{|c|c|c|c|c|c|}
\hline & \multirow[b]{2}{*}{ HPA } & \multirow{2}{*}{$\frac{\text { Non-landed }}{\mathrm{HPH}}$} & \multicolumn{3}{|c|}{ Landed } \\
\hline & & & HPT & HPS & HPD \\
\hline Optimum lags & $(2,0,0,0,0)$ & $(2,1,0,0,1)$ & $(2,0,0,0,0)$ & $(2,1,0,0,0)$ & $(1,1,0,0,0)$ \\
\hline \multicolumn{6}{|l|}{ Bounds test } \\
\hline F-statistic & $6.5598 * * *$ & $6.9206 * * *$ & $6.0008 * * *$ & $3.8608^{*}$ & 2.7496 \\
\hline \multicolumn{6}{|l|}{ Long-run coefficients } \\
\hline GDP & 0.0123 & -0.5543 & -0.0219 & -1.6835 & $-0.9639 * * *$ \\
\hline BLR & 0.2238 & 0.0272 & 0.1102 & 0.0833 & 0.0771 \\
\hline POP & 12.9847 & $11.0444^{* * *}$ & $11.0146 * * *$ & 9.6242 & $5.5833 * * *$ \\
\hline ES & -4.6959 & $-1.7445^{* * *}$ & $-4.0476 * *$ & -0.1236 & 1.3244 \\
\hline$D_{\text {MITR }}$ & 0.0223 & -0.1322 & -0.0123 & -0.2093 & -0.0585 \\
\hline $\mathrm{D}_{\mathrm{DIBS}}$ & 0.2734 & 0.1178 & 0.1366 & 0.1758 & -0.0313 \\
\hline \multicolumn{6}{|l|}{ Short-run coefficients } \\
\hline $\mathrm{ECT}_{\mathrm{t}-1}$ & $-0.0591 * * *$ & $-0.1900 * * *$ & $-0.0944 * * *$ & $-0.0682 * * *$ & $-0.3266 * * *$ \\
\hline GDP & 0.0169 & $0.1881 * * *$ & -0.0168 & 0.0743 & -0.0167 \\
\hline BLR & $0.0206 * *$ & 0.0140 & $0.0230 * *$ & 0.0108 & $0.0498 * *$ \\
\hline POP & 0.6505 & $2.2546^{* *}$ & 0.1361 & 0.5144 & $2.1314^{* *}$ \\
\hline ES & -0.2608 & $0.7302 * * *$ & -0.0374 & 0.0066 & 0.3357 \\
\hline$D_{\text {MITR }}$ & 0.0063 & $-0.0191^{*}$ & -0.0041 & -0.0010 & 0.0088 \\
\hline $\mathrm{D}_{\mathrm{DIBS}}$ & $0.0164 *$ & $0.0229 * *$ & 0.0151 & 0.0029 & -0.0164 \\
\hline \multicolumn{6}{|l|}{ Diagnostic tests } \\
\hline Serial correlation $\left(\chi^{2}\right)$ & $12.7765^{* *}$ & $10.0197 * *$ & $12.1197 * *$ & 4.7107 & 5.9864 \\
\hline Heteroskedasticity $\left(\chi^{2}\right)$ & 6.8127 & 3.5147 & 12.8269 & 7.6938 & 12.7834 \\
\hline Normality $\left(\chi^{2}\right)$ & 0.6930 & 0.7275 & 2.1265 & 3.3660 & 0.5322 \\
\hline RESET (F-statistic) & 0.1731 & 0.1532 & 0.0139 & 2.4511 & $9.5644 * * *$ \\
\hline
\end{tabular}

Note: $* * *(* *)^{*}$ denote significance at $1 \%(5 \%) 10 \%$ respectively. The optimum lags are selected based on Schwarz Information Criteria. The upper and lower bound critical values are from Narayan (2005), case III (unrestricted intercept and no trend) with $\mathrm{n}=55, \mathrm{k}=4$ : $1 \%[4.244,5.726], 5 \%[3.068,4.334], 10 \%$ $[2.578,3.710]$.

of adjustment for the aggregate house prices is about 6 percent, while it is the highest for HPD (i.e. 32.6 percent) and the lowest for HPS (i.e. 6.8 percent). The influence of each economic factor in the short run is slightly different from that in the long run. For the non-landed property, prices of high-rise houses are highly responsive to economic growth, changes in population and changes in quantity of housing stocks. For the landed property, we find that prices of terraced and detached houses respond positively to changes in interest rate. This suggests that increasing interest rate would not be effective in reversing the upward trend of house prices in Malaysia. Riddel (2004) has explained that mortgage interest rates are less likely to influence those who already own homes because their out-of-pocket costs (i.e. home loan instalment) have 
not changed and they are less likely to sell their homes when interest rates increase. Instead, mortgage interest rates are likely to impact those who plan to enter the housing market.

The coefficients of both $D_{\text {MITR }}$ and $D_{\text {DIBS }}$ are not statistically significant in the long run for any type of housing. This implies that tax relief policy and DIBS do not affect house prices in the long run. In the short run, the coefficients of both $D_{\text {MITR }}$ and $D_{\text {DIBS }}$ are significant for HPH only. The magnitudes of both $D_{\text {MITR }}$ and $D_{\text {DIBS }}$ are smaller compared to the other independent variables. This shows that government housing policies have played a smaller and limited role in explaining house prices in Malaysia.

The impact of MITR is likely to be small due to a relatively short period of implementation. Generally, MITR has insignificant impact on house prices in Malaysia. This is in line with studies in the UK such as reported by Barrell et al. (2004) and Gibb and Whitehead (2007). Meanwhile, the negative coefficient of $D_{\text {MITR }}$ for HPH shows that tax relief policy has not resulted in a rise in house prices especially the high-rise houses which are highly demanded in the country. One explanation to this observation could be due to the implementation of MITR policy coinciding with the GFC that reveals a tradeoff effect with this policy. On one hand, MITR is structured to have a positive impact on house prices because it favours homeownership and leads to higher demand in the housing market. On the other hand, it has a price to pay where the government loses its tax revenue. Nevertheless, MITR has a limited impact on house prices in Malaysia. The finding shows that MITR will not cause a significant rise in house prices. During a slowdown of the housing market, the government should consider MITR as a way to providing housing subsidies to house buyers in Malaysia besides improving the homeownership rate among first-time buyers.

For the DIBS, the coefficient of $D_{D I B S}$ is positive and statistically significant for HPA and HPH in the short run. This shows that average house prices and high-rise house prices have increased significantly during periods of DIBS. This finding reveals that DIBS is an important factor that drives up house prices in the short run. During the implementation of DIBS, prices of high-rise houses have increased significantly. The reason could be because there were many high-rise properties especially the high-end condominiums and apartments being featured in DIBS. With the increasing demand for housing accompanied by scarcity of land, developers are likely to build more high-rise units. In order to promote the sales of high-rise units, prices of these properties had been marked up by including DIBS. However, DIBS was less observed in the landed property markets because the property developers did not face difficulty in selling these houses.

\section{Conclusion}

Most evidence of house price determinants in Malaysia focused on economic fundamentals. In this study, we emphasise on government policy interventions in addition to economic factors. Our findings show that in the long run, although none of the economic factors seem to impact aggregate house prices, prices of high-rise, terraced and detached houses are mainly driven by population and quantity of housing stocks in the long run. Economic factors such as income and interest rate appear to show less significant roles in determining long-run house prices in Malaysia. 
The housing policies only play their intended role in the housing market in the short run. The findings of this study suggest that MITR has not caused significant house price increases but DIBS appears to significantly impact the aggregate house prices especially the prices of high-rise housing. As such, this study highlights some important policy implications. Firstly, to ensure stability and sustainable growth of house prices, the government should not allow DIBS to be featured in the sales of properties from developers to house buyers. DIBS is an innovative marketing tool of property sellers that adds an attractive price package on newly built housing. It has unwittingly provided room for eventual property investment and unwanted speculation but has not helped in lowering house prices and providing affordable housing in the country.

Secondly, to ensure housing affordability among first-time buyers, an adequate government subsidy should be provided through tax relief on mortgage loan interest. MITR can be implemented in the primary market to first-time house buyers and the effective date of implementation can be extended for a longer period. The government and policy makers should be prudent in deciding housing policy that ensures a stable growth.

Thirdly, a disadvantage to investors in the property market has arised from government interventions and the implementation of policies that have significantly affected the market and hence influence their investment returns, or can even cause them to suffer losses. Excess returns are likely to be less profitable when the government unexpectedly implements policies to slowdown the property market. In view of the illiquidity of the housing asset, investors are not encouraged to treat housing as an investment asset or "a sure-fire" method to achieve quick and/or large profits by investing in and holding many units. Furthermore, Yeap and Lean (2017) have found that investment in the Malaysian housing market is not effectively hedged against inflation and they also disregard housing as a good investment asset or an attractive investment option. The primary objective and purpose for any country's housing policies should always be to benefit the genuine house buyers who purchase their housing assets for staying with their families. It should never be about encouraging investment and allowing speculation.

We notice that there has been only a relatively small number of studies conducted on MITR and no study had been undertaken on DIBS which severely limits the present research in providing any significant comparisons with previous studies. However, this paper is somewhat pioneering into these largely unchartered waters that are increasingly important for many countries given the growing population and therefore provides a foundation for future research endeavours. Besides these two housing policies, other policies such as the implementation of the goods and services tax (GST) and restrictions on the loan-to-value ratio could be considered in future studies.

\section{References}

Abelson, P., Joyeux, R., Milunovich, G., \& Chung, D. (2005). Explaining house prices in Australia: 1970-2003. Economic Record, 81(255), S96-S103.

Anundsen, A.K. (2015). Econometric regime shifts and the US subprime bubble. Journal of Applied Econometrics, 30(1), 145-169. doi: 10.1002/jae.2367 
Bank Negara Malaysia (BNM). (2009). Annual Report 2009. Kuala Lumpur: Author.

Bank Negara Malaysia (BNM). (2013). Financial Stability Report 2013. Kuala Lumpur: Author.

Barrell, R., Kirby, S., \& Riley, R. (2004). The current position of UK house prices. National Institute Economic Review, 189(July), 57-60.

Buckley, R., \& Ermisch, J. (1982). Government policies and house prices in the United Kingdom: An econometric analysis. Oxford Bulletin of Economics and Statistics, 44(4), 273-304. doi: 10.1111/j.1468-0084.1982.mp44004001.x

Fong, M.H. (2009, March 12). Stimulus spending on property sector insufficient, says Rehda. The Edge Financial Daily.

Gibb, K., \& Whitehead, C. (2007). Towards the more effective use of housing finance and subsidy. Housing Studies, 22(2), 183-200.

Glaeser, E., \& Shapiro, J.M. (2003). The benefits of the home mortgage interest deduction. In James Poterba (Ed.), Tax Policy and the Economy, Volume 17 (pp. 37-82). Cambridge, MA: MIT Press.

Glindro, E.T., Subhanij, T., Szeto, J., \& Zhu, H. (2011). Determinants of house prices in nine AsiaPacific economies. International Journal of Central Banking, 7(3), 163-204.

Hanson, A. (2012). Size of home, homeownership, and the mortgage interest deduction. Journal of Housing Economics, 21(3), 195-210. https://doi.org/10.1016/j.jhe.2012.06.001

Heylen, K. (2013). The distributional impact of housing subsidies in Flanders. International Journal of Housing Policy, 13(1), 45-65. http://dx.doi.org/10.1080/14616718.2013.764660

Himmelberg, C., Mayer, C., \& Sinai, T. (2005). Assessing high house prices: Bubbles, fundamentals and misperceptions. Journal of Economic Perspectives, 19(4), 67-92. doi: 10.1257/ 089533005775196769

Hui, H.C. (2013). Housing price cycles and aggregate business cycles: Stylised facts in the case of Malaysia. Journal of Developing Areas, 47(1), 149-169. doi: 10.1353/jda.2013.0016

Ibrahim, M., \& Law, S.H. (2014). House prices and bank credits in Malaysia: An aggregate and disaggregate analysis. Habitat International, 42(April), 111-120. https://doi.org/10.1016/j. habitatint.2013.11.006

Jappelli, T., \& Pistaferri, L. (2007). Do people respond to tax incentives? An analysis of the Italian reform of the deductibility of home mortgage interests. European Economic Review, 51(2), 247-271. https://doi.org/10.1016/j.euroecorev.2006.04.003

Kenny, G. (1999). Modelling the demand and supply sides of the housing market: Evidence from Ireland. Economic Modelling, 16(3), 389-409.

Kenny, G. (2003). Asymmetric adjustment costs and the dynamics of housing supply. Economic Modelling, 20(6), 1097-1111. https://doi.org/10.1016/S0264-9993(02)00066-4

Lean, H.H., \& Smyth, R. (2014). Dynamic interaction between house prices and stock prices in Malaysia. International Journal of Strategic Property Management, 18(2), 163-177. http:// dx.doi.org/10.3846/1648715X.2014.925006

Li, Q., \& Chand, S. (2015). Market fundamentals, rational expectation and housing price changes: Evidence from housing market in Beijing. Housing, Theory and Society, 32(3), 289-301. http://dx.doi.org/10.1080/14036096.2015.1043470

Lum, S.K. (2002). Market fundamentals, public policy and private gain: House price dynamics in Singapore. Journal of Property Research, 19(2), 121-143. http://dx.doi.org/10.1080/ 09599910210125232

Malpezzi, S., \& Maclennan, D. (2001). The long-run price elasticity of supply of new residential construction in the United States and the United Kingdom. Journal of Housing Economics, 10(3), 278-306. https://doi.org/10.1016/jhec.2001.0288

Matsaganis, M., \& Flevotomou, M. (2007). The impact of mortgage interest tax relief in the Netherlands, Sweden, Finland, Italy and Greece (Euromod working paper no. EM2/07). Colchester, UK: Institute for Social and Economic Research, University of Essex 
McCarthy, J., \& Peach, R.W. (2004). Are home prices the next 'bubble'? Federal Reserve Bank of New York Economic Policy Review, 10(3), 1-17.

Meen, G. (2002). The time-series behavior of house prices: A transatlantic divide? Journal of Housing Economics, 11(1), 1-23. https://doi.org/10.1016/jhec.2001.0307

Munro, M., \& Tu, Y. (1996). The dynamics of UK national and regional house prices. Review of Urban \& Regional Development Studies, 8(2), 186-201. doi: 10.1111/j.1467-940X.1996. tb00117.x

Narayan, P.K. (2005). The saving and investment nexus for China: Evidence from cointegration tests. Applied Economics, 37(17), 1979-1990. http://dx.doi.org/10.1080/00036840500278103

Otto, G. (2007). The growth of house prices in Australian capital cities: What do economic fundamentals explain? Australian Economic Review, 40(3), 225-238. doi: 10.1111/j.1467-8462. 2007.00453.x

Pesaran, M.H., Shin, Y., \& Smith, R.J. (2001). Bounds testing approaches to the analysis of level relationships. Journal of Applied Econometrics, 16(3), 289-326. doi: 10.1002/jae.616

Phang, S.Y., \& Wong, W.K. (1997). Government policies and private housing prices in Singapore. Urban Studies, 34(11), 1819-1829. http://dx.doi.org/10.1080/0042098975268

Poon, J., \& Garratt, D. (2012). Evaluating UK housing policies to tackle housing affordability. International Journal of Housing Markets and Analysis, 5(3), 253-271. https://doi.org/ $10.1108 / 17538271211243599$

Poterba, J.M. (1991). House price dynamics: The role of tax policy and demography. Brookings Papers on Economic Activity, 22(2), 143-203.

Poterba, J.M. (1992). Taxation and housing: Old questions, new answers. The American Economic Review, 82(2), 237-242.

Riddel, M. (2004). Housing-market disequilibrium: An examination of housing-market price and stock dynamics 1967-1998. Journal of Housing Economics, 13(2), 120-135. https://doi. org/10.1016/j.jhe.2004.04.002

Rosen, H.S. (1985). Housing subsidies: Effects on housing decisions, efficiency, and equity. In Martin Feldstein \& A.J. Auerbach (Eds.), Handbook of Public Economics, Volume 1 (pp. 375420). Amsterdam, Holland: North Holland Publishing Co. https://doi.org/10.1016/S15734420(85)80010-0

Steiner, E. (2010). Estimating a stock-flow model for the Swiss housing market. Swiss Journal of Economics and Statistics, 146(3), 601-627.

Stevenson, S. (2008). Modeling housing market fundamentals: Empirical evidence of extreme market conditions. Real Estate Economics, 36(1), 1-29. doi: 10.1111/j.1540-6229.2008. 00204.x

Stevenson, S., \& Young, J. (2014). A multiple error-correction model of housing supply. Housing Studies, 29(3), 362-379. http://dx.doi.org/10.1080/02673037.2013.803040

Tang, T.C., \& Tan, P.P. (2015). Real interest rate and house prices in Malaysia: An empirical study. Economics Bulletin, 35(1), 270-275.

$\mathrm{Tu}, \mathrm{Y}$. (2003). The macro impacts of public resold dwellings on private housing prices in Singapore. Review of Urban and Regional Development Studies, 15(3), 191-207. doi: 10.1111/j.1467940X.2003.00072.x

Wigren, R., \& Wilhelmsson, M. (2007). Housing stock and price adjustments in 12 West European countries between 1976 and 1999. Housing, Theory and Society, 24(2), 133-154. http:// dx.doi.org/10.1080/14036090601119589

Yeap, G.P., \& Lean, H.H. (2017). Asymmetric inflation hedge properties of housing in Malaysia: New evidence from nonlinear ARDL approach. Habitat International, 62(April), 11-21. https://doi.org/10.1016/j. habitatint.2017.02.006

Zhou, J. (2010). Testing for cointegration between house prices and economic fundamentals. Real Estate Economics, 38(4), 599-632. doi: 10.1111/j.1540-6229.2010.00273.x 